\title{
Prevalence of smoking in Bahrain
}

\author{
Randah R Hamadeh, Klim McPherson, Richard Doll
}

\begin{abstract}
Objective To determine (a) the prevalence of smoking and its distribution by demographic characteristics in the general population of Bahrain; (b) the types and pattern of smoking; and (c) smoking trends.

Design Analysis of smoking and demographic questions from a $4.5 \%$ sample of households. The survey was conducted between September 1981 and February 1983. A two stage sampling design was used, the block being the first stage unit and the household the second stage unit. Setting A national morbidity survey in Bahrain, Arabian Gulf.

Subjects A total of 9282 adults aged 15 and over.

Results The prevalence of smoking was $33.1 \%$ among men and $9.2 \%$ among women. Non-Bahraini men had the highest prevalence of smoking (40.4\%) followed by Bahraini men (30.6\%), Bahraini women $(9.5 \%)$, and non-Bahraini women $(7.9 \%)$. Cigarette smoking was the most popular type of smoking followed by the waterpipe. The latter was more prevalent among Bahraini women than men, but has begun to decrease in both sexes.

Conclusion The prevalence of smoking among men and women in Bahrain was lower than in most of the developed and developing countries. However, a secular trend of increasing cigarette smoking was seen.
\end{abstract}

College of Medicine and Medical Sciences, Arabian Gulf University, PO Box 22979, Bahrain, Arabian Gulf R R Hamadeh

Health Promotion Sciences Unit, Department of Public Health and Policy, London School of Hygiene and Tropical Medicine, London WC1E 7HT, United Kingdom K McPherson

Cancer Studies Unit University of Oxford, Harkness Building, Radcliffe Infirmary, Oxford OX2 6HE, United Kingdom R Doll

Correspondence to: Professor Hamadeh.
$51.8 \%$ of men and $12.1 \%$ of women aged 20 years and above are reported to smoke. ${ }^{8}$

The exact date of tobacco introduction to Bahrain is uncertain. However, it can be assumed that it was brought to Bahrain at the beginning of the eighteenth century, similar to Saudi Arabia and other countries in the region. ${ }^{9}$ All forms of tobacco are imported in Bahrain as there is no cultivation of tobacco or manufacture of tobacco products.

The objectives of this study were $(a)$ to determine the prevalence of smoking and its distribution by demographic characteristics in the general population of Bahrain, (b) to determine the types and pattern of smoking, and $(c)$ to study smoking trends.

\section{Methods}

A national morbidity survey based on a $4.5 \%$ sample of total households (58798) in Bahrain was conducted between September 1981 and February 1983 by the Ministry of Health, with a response rate of $99.5 \%$. The national morbidity survey is the first and only survey to be done in Bahrain and the Gulf States to date.

Bahrain is divided into 11 regions, 10 of which are inhabited. These regions in turn are divided into area blocks containing varying number of households.

A two stage sampling design was used, the block being the first stage unit and the household the second stage unit. At the first stage a stratified random sample of blocks was chosen using the regions as strata; in the second stage a systematic sample of households was chosen from the selected blocks. The blocks were selected with probability proportional to the number of households contained in them. ${ }^{10}$

At the time of designing the survey smoking was just one of the variables included and no special emphasis was given to it. Hence, smoking related questions (appendix) along with the others were put to the head of the household or eldest person in the presence of adult members of the family and were intended to identify current smokers in the household and their type and frequency of smoking. Data on ex-smokers, however, were not collected. Information on smoking was obtained for all the 4785 men and 4497 women who were aged 15 years and over. Cigarette smokers were considered to be regular light smokers if they smoked less than one packet a day and regular heavy smokers if they smoked one packet or more daily; otherwise they were classified as occasional smokers (less than one cigarette a day). Waterpipe smokers were classified as 
Table 1 Prevalence of smoking (\%) by age, sex, and nationality in the national morbidity survey

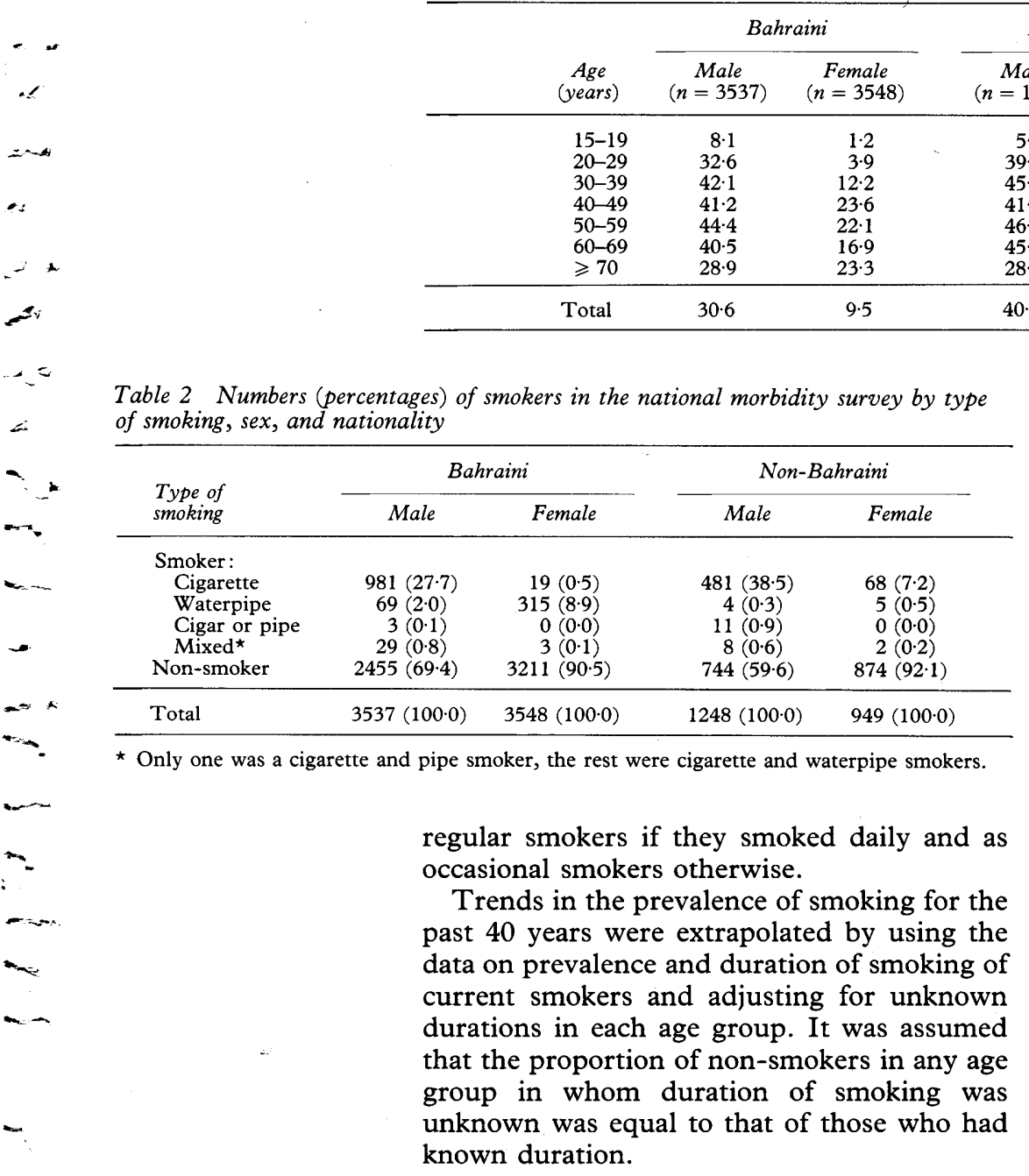

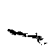

\section{Frequency}

- $\quad$ of smoking

Non-smoker Smoker:

Table 3 Numbers (percentages) of cigarette and waterpipe smokers in the national morbidity survey by frequency of smoking, nationality, and

\section{Results}

The population distribution of those aged 15 years and over was similar in terms of age, sex, and nationality in the national morbidity survey and the 1981 census.

The prevalence of smoking at ages 15 years and over was $33.1 \%$ among men and $9.2 \%$ among women in Bahrain (table 1). The highest percentage was in non-Bahraini men overall $(40.4 \%)$ and in those aged $50-59$ years $(46.9 \%)$. The percentage of Bahraini male and female smokers was $30.6 \%$ and $9.5 \%$, respectively. The highest frequency of smoking for Bahraini men (44.4\%) was in those aged 50-59 and for Bahraini females in those aged $40-49(23.6 \%)$ and 70 and over $(23.3 \%)$.
Table 2 shows that cigarette smoking including cigarettes mixed with other types of smoking was more prevalent among nonBahraini men (39.2\%), followed by Bahraini men $(28.6 \%)$, non-Bahraini women $(7.4 \%)$, and Bahraini women $(0.6 \%)$.

Waterpipe smoking was more widespread among the Bahraini women $(9.0 \%)$ than in the other groups. Pipe and cigar smoking were not common in Bahrain, especially among the Bahraini.

Forty four per cent of the cigarette smokers were regular light smokers ( $<1$ packet a day). A third of the Bahraini male smokers were heavy smokers ( $\geqslant 1$ packet a day) compared with a fifth of the non-Bahraini male cigarette smokers. Half of the waterpipe smokers were regular (daily) smokers and the other half occasional (less than daily) smokers (table 3 ).

The majority of smokers started smoking in the age groups $10-19$ years $(43.3 \%)$ and $20-29$ $(44.5 \%)$. The age at starting smoking was unknown for $29.0 \%$ of the smokers (table 4). The average age at starting to smoke was similar for cigarette smokers (21.3 years) and for waterpipe smokers (23.3 years) in all groups except in Bahraini men, in whom the mean ages at starting were respectively 21.0 years and 31.0 years.

The data on duration of smoking were available for $78.4 \%$ of the cigarette and $38.2 \%$ of the waterpipe smokers. These showed that both cigarette and waterpipe smoking have been prevalent in Bahrain for at least the past 50 years. Throughout this period the prevalence of cigarette smoking was found to have increased in all age groups while the prevalence of waterpipe smoking decreased (table 5). In young women the prevalence of waterpipe smoking is decreasing, but in older women it has become more frequent. Cigarette smoking by women began only in the 1970s and is still very uncommon.

\begin{tabular}{|c|c|c|c|c|c|c|c|c|c|}
\hline $\begin{array}{l}= \\
\therefore-\infty\end{array}$ & $\begin{array}{l}\text { Smoker: } \\
\text { Occasional } \\
\text { Regular light } \\
\text { Regular heavy } \\
\text { Undetermined }\end{array}$ & $\begin{array}{l}242(6 \cdot 8) \\
441(12 \cdot 5) \\
317(9 \cdot 0) \\
10(0 \cdot 3)\end{array}$ & $\begin{array}{r}11(0 \cdot 3) \\
2(0 \cdot 1) \\
6(0 \cdot 2) \\
3(0 \cdot 1)\end{array}$ & $\begin{array}{l}154(12 \cdot 3) \\
231(18 \cdot 5) \\
103(8 \cdot 3) \\
1(0 \cdot 1)\end{array}$ & $\begin{array}{r}28(3 \cdot 0) \\
31(3 \cdot 3) \\
8(0 \cdot 8) \\
3(0 \cdot 3)\end{array}$ & $\begin{array}{c}46(1 \cdot 3) \\
51(1.4) \\
0(0 \cdot 0)\end{array}$ & $\begin{array}{r}156(4.4) \\
160(4.5) \\
0(0.0) \\
2(0.1)\end{array}$ & $\begin{array}{l}9(0 \cdot 7) \\
3(0 \cdot 3) \\
0(0 \cdot 0) \\
0(0.0)\end{array}$ & $\begin{array}{l}5(0.5) \\
2(0.2) \\
0(0 \cdot 0) \\
0(0 \cdot 0)\end{array}$ \\
\hline & Total & $3537(100 \cdot 0)$ & $3548(100 \cdot 0)$ & $1248(100 \cdot 0)$ & $949(100 \cdot 0)$ & $3537(100 \cdot 0)$ & $3548(100 \cdot 0)$ & $1248(100 \cdot 0)$ & $949(100 \cdot 0)$ \\
\hline
\end{tabular}


Table 4 Numbers (percentages) of all smokers in the national morbidity survey by age and age at starting smoking

\begin{tabular}{|c|c|c|c|c|c|c|}
\hline \multirow{2}{*}{$\begin{array}{c}\text { Age } \\
\text { (years) }\end{array}$} & \multicolumn{4}{|c|}{ Age at starting smoking (years) } & \multirow[b]{2}{*}{ Total } & \multirow{2}{*}{$\begin{array}{l}\% \text { of smokers } \\
\text { with age at } \\
\text { starting smoking } \\
\text { unknown }\end{array}$} \\
\hline & $10-19$ & $20-29$ & $30-39$ & $\geqslant 40$ & & \\
\hline $\begin{array}{c}15-19 \\
20-29 \\
30-39 \\
40-49 \\
50-59 \\
60-69 \\
\geqslant 70\end{array}$ & $\begin{aligned} & 60(100 \cdot 0) \\
& 261(60 \cdot 4) \\
& 144(38 \cdot 2) \\
& 79(28 \cdot 4) \\
& 41(24 \cdot 3) \\
& 19(25 \cdot 7) \\
& 10(34 \cdot 5)\end{aligned}$ & $\begin{array}{r}0(0 \cdot 0) \\
171(39 \cdot 6) \\
207(54 \cdot 9) \\
140(50 \cdot 4) \\
78(46 \cdot 2) \\
26(35 \cdot 1) \\
9(31 \cdot 0)\end{array}$ & $\begin{array}{c}0(0 \cdot 0) \\
0(0.0) \\
26(6.9) \\
48(17 \cdot 3) \\
32(18.9) \\
10(13.5) \\
0(0.0)\end{array}$ & $\begin{array}{c}0(0 \cdot 0) \\
0(0 \cdot 0) \\
0(0 \cdot 0) \\
11(4 \cdot 0) \\
18(10 \cdot 7) \\
19(25 \cdot 7) \\
10(34 \cdot 5)\end{array}$ & $\begin{array}{r}60(100 \cdot 0) \\
432(100 \cdot 0) \\
377(100 \cdot 0) \\
278(100 \cdot 0) \\
169(100 \cdot 0) \\
74(100 \cdot 0) \\
29(100 \cdot 0)\end{array}$ & $\begin{array}{l}29 \cdot 4 \\
23 \cdot 3 \\
26 \cdot 7 \\
29 \cdot 3 \\
34 \cdot 0 \\
38 \cdot 3 \\
49 \cdot 1\end{array}$ \\
\hline Total & $614(43 \cdot 3)$ & $631(44.5)$ & $116(8 \cdot 2)$ & $58(4 \cdot 1)$ & $1419(100 \cdot 0)$ & $29 \cdot 0$ \\
\hline
\end{tabular}

Table 5 Prevalence of smoking (\%) among Bahraini men and women by type of smoking (1940-1980)

\begin{tabular}{|c|c|c|c|c|c|c|c|c|c|c|}
\hline \multirow{2}{*}{$\begin{array}{c}\text { Age } \\
\text { (years) }\end{array}$} & \multicolumn{5}{|c|}{ Men } & \multicolumn{5}{|c|}{ Women } \\
\hline & $1980 \mathrm{~s}$ & $1970 \mathrm{~s}$ & $1960 \mathrm{~s}$ & $1950 \mathrm{~s}$ & $1940 \mathrm{~s}$ & $1980 \mathrm{~s}$ & $1970 \mathrm{~s}$ & $1960 \mathrm{~s}$ & $1950 \mathrm{~s}$ & $1940 \mathrm{~s}$ \\
\hline $\begin{array}{l}20-29 \\
30-39 \\
40-49 \\
50-59 \\
60-69\end{array}$ & $\begin{array}{l}32 \cdot 6 \\
42 \cdot 1 \\
41 \cdot 2 \\
44 \cdot 4 \\
40 \cdot 5\end{array}$ & $\begin{array}{l}32 \cdot 6 \\
38 \cdot 1 \\
43 \cdot 0 \\
38 \cdot 8\end{array}$ & $\begin{array}{l}29 \cdot 0 \\
36 \cdot 3 \\
36 \cdot 3\end{array}$ & $\begin{array}{l}25 \cdot 0 \\
26 \cdot 1\end{array}$ & $\begin{array}{l}\text { All types } \\
12 \cdot 7\end{array}$ & $\begin{array}{r}3.9 \\
12 \cdot 2 \\
23.6 \\
21.9 \\
16 \cdot 9\end{array}$ & $\begin{array}{l}10.4 \\
20.7 \\
20.9 \\
16.9\end{array}$ & $\begin{array}{l}16.2 \\
19.9 \\
16.9\end{array}$ & $\begin{array}{l}16 \cdot 2 \\
16 \cdot 9\end{array}$ & $14 \cdot 1$ \\
\hline $\begin{array}{l}20-29 \\
30-39 \\
40-49 \\
50-59 \\
60-69\end{array}$ & $\begin{array}{l}32 \cdot 1 \\
41 \cdot 5 \\
38 \cdot 6 \\
38 \cdot 2 \\
30 \cdot 9\end{array}$ & $\begin{array}{l}33 \cdot 0 \\
35 \cdot 6 \\
37 \cdot 0 \\
29 \cdot 7\end{array}$ & $\begin{array}{l}27 \cdot 0 \\
32 \cdot 0 \\
28 \cdot 0\end{array}$ & $\begin{array}{l}23 \cdot 1 \\
22 \cdot 2\end{array}$ & $\begin{array}{c}\text { Cigarettes } \\
14 \cdot 0\end{array}$ & $\begin{array}{l}0.6 \\
0.7 \\
1 \cdot 4 \\
0 \cdot 3 \\
0 \cdot 0\end{array}$ & $\begin{array}{l}0 \cdot 7 \\
0.7 \\
0 \cdot 0 \\
0 \cdot 0\end{array}$ & $\begin{array}{l}0 \cdot 0 \\
0.0 \\
0 \cdot 0\end{array}$ & $\begin{array}{l}0 \cdot 0 \\
0 \cdot 0\end{array}$ & 0.0 \\
\hline $\begin{array}{l}20-29 \\
30-39 \\
40-49 \\
50-59 \\
60-69\end{array}$ & $\begin{array}{r}1 \cdot 0 \\
1 \cdot 0 \\
2 \cdot 8 \\
8 \cdot 3 \\
12 \cdot 7\end{array}$ & $\begin{array}{r}0 \cdot 5 \\
2 \cdot 8 \\
7 \cdot 7 \\
11 \cdot 4\end{array}$ & $\begin{array}{r}2 \cdot 8 \\
5 \cdot 7 \\
11 \cdot 4\end{array}$ & $\begin{array}{l}0 \cdot 0 \\
8 \cdot 1\end{array}$ & $\begin{array}{c}\text { Waterpipe } \\
3.6\end{array}$ & $\begin{array}{r}3.4 \\
11.7 \\
22.3 \\
21.5 \\
19.9\end{array}$ & $\begin{array}{r}9 \cdot 7 \\
19 \cdot 0 \\
20 \cdot 3 \\
16 \cdot 9\end{array}$ & $\begin{array}{l}14 \cdot 8 \\
20 \cdot 3 \\
16 \cdot 9\end{array}$ & $\begin{array}{l}16 \cdot 5 \\
16 \cdot 9\end{array}$ & 0.0 \\
\hline
\end{tabular}

About $80 \%$ of the cigarette smokers provided data at interview on the brand smoked. Dunhill, Rothmans, Kent, Silk Cut, and Marlboro King Size, were the five brands most commonly smoked. Analysis of cigarette brand smoked by age showed that Dunhill was the most popular brand in all age groups. Rothmans and Silk Cut, however, were less favoured by the young in comparison with Kent and Marlboro. Marlboro was the most favoured brand among those aged 15-19 years.

Single men had a lower prevalence of smoking $(12.9 \%)$ than all people who had ever been married (23.1-29.4\%). The prevalence of smoking among the university degree holders $(27.7 \%)$ was almost equal to that of the illiterate $(26.2 \%)$. The proportion of smokers was lowest among those with an intermediate $(15.6 \%)$ and secondary $(15.1 \%)$ education. Income support recipients $(43.5 \%)$ and labourers $(43.0 \%)$ had a higher prevalence of smoking than professionals $(26.4 \%)$ and clerical workers $(24.9 \%)$.

\section{Discussion}

The prevalence of smoking in men and women in Bahrain is generally lower than that in their counterparts in many developed ${ }^{11}$ and developing countries (M Khlat and HK Armenian, unpublished report). ${ }^{812}$ The proportion of adult male cigarette smokers in Bahrain is $31.3 \%$ and $37.6 \%$ in those aged 15 and above and 20 and above, respectively. The corresponding figures in the United Kingdom, ${ }^{13}$ Australia, ${ }^{14}$ and Canada ${ }^{15}$ in the early 1980s in those aged 15 and above ranged from $37.0 \%$ to $41.0 \%$; those in Lebanon ( $M$ Khlat and HK Armenian, unpublished report), Kuwait, ${ }^{8}$ and Japan ${ }^{16}$ ranged from $46.2 \%$ to $70.2 \%$ in people of 20 and over. However, in the United States ${ }^{17}$ the figure $(38.0 \%)$ is almost equal to that of Bahrain (37.6\%). On the other hand, the proportion of female smokers in Bahrain is much lower than that in industrial countries apart from Japan. ${ }^{13-17}$

However, the prevalence of smoking among females in Bahrain exceeds that of most nonArab developing countries that have available data but is lower than the rate for Arab females (M Khlat and HK Armenian, unpublished report). ${ }^{812}$

A comparison with the smoking rates of Kuwait (NA Al-Naqeeb, unpublished data), ${ }^{8}$ a country with similar religious, ethnic, and cultural habits, suggests that the prevalence of smoking is lower in Bahrain. Among those aged 20 years and above the prevalence of smoking in males of Bahrain (39.4\%) is lower than that of their Kuwaiti counterparts $(51.8 \%)$, in spite of the fact that the Kuwaiti data were restricted to cigarette smoking only. The proportion of female smokers in that age group is almost similar. However, a large difference results when cigarette smoking alone is considered. The percentage of female cigarette smokers aged 20 years and above in Bahrain drops to $2.4 \%$ compared with $12.1 \%$ in Kuwait. Further analysis by nationality and smoking prevalence between the two countries shows that smoking is more prevalent in Kuwait (NA Al-Naqeeb, unpublished data) 
particularly among females. The proportion of cigarette smokers in those aged 20 and above is $0.8 \%$ in Bahraini females compared with $7.5 \%$ in Kuwaiti females. The corresponding percentages among males are $35.8 \%$ and $42.7 \%$.

The difference between the prevalence of smoking in Bahrain and in Kuwait may, however, be due to underestimation in the Bahrain data because of the method used to obtain data. The head of the household was usually the interviewee in the Bahrain study and the head might not mention a female cigarette smoker or a young male smoker because of its negative social connotation.

Moreover, the interviewee might not be aware that a female member of the family smokes as she would do so in private. The Kuwaiti data on the other hand were based on a personal interview as part of a cross sectional study. $^{8}$

The proportion of smokers who started smoking during their teenage $(36.6 \%)$ is lower than that reported for Egypt $(52.9 \%)^{18}$ and Lebanon $(69.0 \%){ }^{19}$

From the data on duration of smoking, it is evident that cigarette smoking has been practised among males in Bahrain for over 50 years. It is possible that it was imported into Bahrain shortly after being taken up in developed countries at the turn of the twentieth century. ${ }^{20-22}$ On the other hand, cigarette smoking by Bahraini females was delayed until the 1970 s. In contrast, waterpipe smoking has been popular in the country much longer than cigarettes, as tobacco smoking in waterpipes was probably practised as early as the eighteenth century in Bahrain as in neighbouring countries. ${ }^{22} 23$

The prevalence of smoking has been almost stable in all age groups in Bahrain for the past 50 years. But further analysis by type of smoking shows that smoking of cigarettes has increased and that of waterpipes has decreased, particularly in the young. Because data on exsmokers were not collected, the trend in cigarette smoking has to be interpreted cautiously. However, there is no reason to believe that the proportion of ex-smokers varied during this period of time as serious efforts to educate the public of the harmful effects of smoking and legislative measures to control smoking only began in $1979 .^{10}$

It is worth noting that Dunhill, although the leading brand smoked in Bahrain, is not among the five most popular brands in most of the countries that have published data, apart from Cyprus. ${ }^{24}$ However, Rothmans, Silk Cut, and Marlboro are also among the most preferred brands in industrial countries. ${ }^{2526}$

The relatively high proportion of smokers among the university degree holders $(27.7 \%)$ and its similarity to that of the illiterate $(26.2 \%)$ is contrary to what has been reported for industrialised countries. ${ }^{2627}$ Smoking among professionals was found to be $26.4 \%$ in contrast to the results of a recent study on smoking among physicians, journalists, and teachers in Bahrain where the proportions of smokers were $60.1 \%, 77.4 \%$, and $80.6 \%$, respectively. ${ }^{6}$ However, the response rate in the latter study was only $49 \cdot 2 \%$.

We conclude that about a third of the men in Bahrain smoke and that there has been a secular trend of increasing cigarette smoking. Knowledge of the risks associated with smoking has not yet brought about any decrease in its prevalence in Bahrain.

We are grateful to the Bahrain Ministry of Health and to Drs Rashid Fuleifel and Ali Matar in particular for their support and assistance. We acknowledge all those who contributed in the national morbidity survey, particularly Drs Haroutune Armenian, Huda Zurayk, Salam Simaan, and Haifa Nabali. We also thank ASH (Action on Smoking and Health) and War on Want in the United Kingdom for allowing us to use their library facilities.

\section{Appendix}

Smoking related questions in the national morbidity survey

1 Does anyone in this household smoke cigarettes ?

If yes: How many cigarettes does he/she smoke per day?

What brand of cigarettes does he/she smoke? At what age did he/she start smoking?

2 Does anyone in this household smoke hubble bubble [waterpipe]?

If yes: How much does he/she smoke per day? At what age did he/she start smoking?

1 Directorate of Statistics, Ministry of Cabinet Affairs, State of Bahrain. Bahrain census of population and housing 1981. Bahrain: Arabian Printing and Publishing House, 1982: 510 .

2 Taha A, Bener A, Noah MS, Saeed A, Al-Harthy S. Smoking habits of King Saud University students in Riyadh. Annals of Saudi Medicine 1991; 11 : 141-3.

3 Saeed AAW, Taha AM, Al-Shahri AH. Smoking habits of physicians in Riyadh, Saudi Arabia Saudi Medical Fournal 1989; 10: 508-11.

4 Rowlands DF, Shipster PJ. Cigarette smoking amongst Saudi schoolboys. Saudi Medical fournal 1987; 8:613-8.

5 Saeed A. Smoking habits of students in College of Allied Medical Sciences, Riyadh. $\mathcal{J} R$ Soc Health 1987; 5: Medical

Thends of tobacco smoking among physicians, journalists and teachers in Bahrain. Bahrain Medical Bulletin 1986; 8 (1): 19-23.

7 Afif LA. An exploratory study to investigate the determinants of health behavior towards smoking in Bahraini secondary school males [PhD thesis]. Iowa: University of Iowa, 1983.

8 El-Desouky M, Hussein K, Ibrahim AS, Al-Hamad A. In: Al-Awadi R, ed. Blood pressure level and epidemiology of hypertension in Kuwait. Kuwait: Department of Social Research, Council of Ministers Secretarial General, 1980: 355.

9 Armoush H. Smoking. Those who support it and those who offend it (Arabic). Cairo: 1979. Cited in: Zahran F. Alcohol, its harm and determinants. A comparative study in Islamic jurisdiction [Arabic]. Cairo: Dar Misr Press, 1983: 315 .

10 Hamadeh RR. The impact of smoking in Bahrain [DPhil thesis]. Oxford: University of Oxford, 1987.

11 Van Reek J. Smoking by adults in the European Community: 1963 and 1987. F Public Health Med 1991; 13: 137.

12 World Health Organisation. Smoking and health in Asia. WHO Chronicle 1982; 36: 156-9.

13 Office of Population Censuses and Surveys. General household survey : cigarette smoking 1972 to 1982 . London: Information Branch, 1983. (OPCS monitor GHS 83/3)

14 Hill D, Gray N. Australian patterns of tobacco smoking and related health beliefs in 1983. Community Health Stud 1984; 8: 307-16.

15 Josse D. Smoking behaviour in Canadians, 1983 . Ottawa: Supply and Services, Canada. (Catalogue No 39-66/1985 Supply and Services, Canada. (Catalogue No 39-66/1985 E.) Cited in: IARC. Tobacco smoking. IARC monographs
on the evaluation of the carcinogenic risk of chemicals to on the evaluation of the carcinogenic risk of chemicals to
humans. Lyons: IARC, 1986:77. (IARC monographs vol 38.)

16 Tominaga $S$. The future problem. Smoking in Japan. In: Tominaga $\mathrm{S}$, Aoki $\mathrm{K}$, eds. The UICC smoking control workshop, Nagoya, Japan August 24-25, 1981. Nagoya: University of Nagoya Press, 1982: 27-35.

17 US Department of Health and Human Services. The health consequences of smoking : cardiovascular disease. A report of the Surgeon General. Rockville, Maryland: US Department of Health and Human Services, Office on Smoking and Health, 1983: 384 .

18 Tobia-Hanna A, Wahdan MH. Studies on smoking. I. Epidemiology of smoking. $\mathcal{F}$ Egypt Public Health Assoc 1964; 39: 353-69. 
19 Nassar NT, Zurayk HC, Salem PA. Smoking patterns among students in Lebanon. Fournal of the American among students in Lebanon. Fournal of the

20 US Department of Health, Education, and Welfare. Department of Health, Education, and Welfare. Smoking and health. A report of the Surgeon General. Department of Health, Education, and Welfare, Public Health Service, Office of the Assistant Secretary for Health, Office on Smoking and Health. Washington, DC: DHEW, 1979. (DHEW Publication No (PHS) 7950066.)

21 Royal College of Physicians. Smoking and health. Tunbridge Wells: Pitman Medical, 1962: 69

\section{Translations of abstract}

\section{La prévalence du tabagisme au Bahreïn \\ Randah R Hamadeh et al \\ Résumé}

Objectif: Déterminer (a) la prévalence du tabagisme et sa répartition par caractéristiques démographiques dans la population globale du Bahreïn; $(b)$ les types et les modèles de consommation; et $(c)$ les tendances tabagiques.

Méthode: Analyse des habitudes tabagiques et des facteurs démographiques d'un échantillon de $4,5 \%$ de ménages. L'étude a été réalisée entre septembre 1981 et février 1983. L'échantillonage a été fait en deux stades, le groupe étant l'unité du premier stade et le ménage l'unité du deuxième stade.

Cadre: Une étude nationale sur la morbidité au Bahreïn, Golfe d'Arabie.

Sujets: 9282 adultes agés de 15 ans et plus.

Résultats: La prévalence du tabagisme était de 33,1\% chez les hommes et de $9,2 \%$ chez les femmes. Le pourcentage de fumeurs était le plus élévé chez les hommes non-originaires du Bahrein (40,4\%), suivi par les hommes Bahreïni $(30,6 \%)$, les femmes Bahreïni $(9,5 \%)$ et les femmes non-originaires de Bahreïn $(7,9 \%)$. La consommation de cigarettes était la forme la plus populaire du tabagisme suivi par la pipe à eau. Celle-ci était plus répandue parmi les femmes Bahreïni que parmi les hommes mais elle a toutefois commencé à diminuer parmi les deux sexes.

Conclusion: La prévalence du tabagisme parmi les hommes et les femmes au Bahreï était moins élévée que dans la plupart des pays développés ou en voie de développement. Cependant, on constante que la consommation de cigarettes a tendance à augmenter.
22 Zahran F. Alcohol, its harm and determinants. A comparative study in Islamic jurisdiction [Arabic]. Cairo: Dar Misr study in Islamic

23 Sharaf AAA. Smoke and smoking [Arabic]. Cairo: Dar AlMaarif, 1972: 163 .

24 Maxwell. World Tobacco 1981. July: 61-6.

24 Maxwell. World Tobacco 1981. July: 61-6.

26 Gray NJ, Hill DJ. Patterns of tobacco smoking in Australia Gray NJ, Hill DJ. Patterns of tobacd
2. Med f Aust 1977; 2: 327-8.

27 Pierce JP. Progress and problems in international public health efforts to reduce tobacco usage. Annu Rev Publ Health 1991 ; 12 : 383-400.

\section{Prevalencia de tabaquismo en Bahrein \\ Randah R Hamadeh et al}

\section{Resumen}

Objetivo: Determinar (a) la prevalencia del tabaquismo en la población general de Bahrein y su distribución según características demográficas; (b) los tipos y la modalidad del tabaquismo; y (c) las tendencias de tabaquismo.

Diseño: Análisis del tabaquismo y preguntas demográficas a partir de una muestra del $4,5 \%$ de los hogares. La encuesta se realizó entre septiembre de 1981 y febrero de 1983. Se empleó un diseño de muestreo en dos etapas: la manzana de casas se consideró como unidad de la primera etapa y el hogar, como unidad de la segunda.

Marco: Encuesta nacional de morbilidad en Bahrein, Golfo de Arabia.

Sujetos: Un total de 9282 adultos de 15 y más años de edad.

Resultados: La prevalencía del tabaquismo fue de $33,1 \%$ entre los hombres y $9,2 \%$ entre las mujeres. $\mathrm{La}$ prevalencia más alta $(40,4 \%)$ se observó en los hombres no originarios de Bahrein, seguida por las correspondientes a los hombres nacionales de Bahrein $(30,6 \%)$, las mujeres de Bahrein $(9,5 \%)$ y las mujeres no oriundas de Bahrein (7,9\%). El fumar cigarrillos fue el tipo más popular de tabaquismo, seguido por la pipa. La prevalencia de esta última fue más alta entre las mujeres de Bahrein que entre los hombres, si bien su uso por los dos sexos ha comenzado a disminuir.

Conclusión: La prevalencia de tabaquismo en los hombres y mujeres de Bahrein fue menor que en la mayoria de los paises desarrollados y en vias de desarrollo. Sin embargo, se observa una tendencia al creciente consumo de cigarrillos.

\section{巴林的吸烟率 兰德・汉姆德}

研究目的: 确定 1) 在巴林的不同人群中吸烟率的分布情况；2) 常见的烟草种类和吸烟方 式；3) 吸烟率的变化趋势。

研究设计：调查于 1981 年 9 月至 1983 年 2 月之间进行, 本研究采用二阶段抽样调查设计, 第一阶段的基本单元是街区, 第二阶段的基本单元是家庭, 共有 $4.5 \%$ 的家庭被调查, 调查 内容包括吸烟情况及某些人口学问题。

抽样范围: 巴林全国疾病发病率调查时所规定的人群

研究对象：9282 名 15 岁以上的成年人

研究结果: 男性吸烟率为 33.1\%, 而女性吸烟率为 $9.2 \%$, 非巴林籍男性吸烟率最高 $(40.4 \%$, 其 次巴林男性 $(30.6 \%)$ 巴林女性 $(9.5 \%)$ 非巴林籍女性 $(7.9 \%)$ 。烟草种类主要为卷烟, 其次为 水烟。在巴林, 女性吸烟较男性更为普遍。但近年来, 吸水烟的人越来越少。

结论: 巴林男女吸烟率低于多数的发达和不发达国家的吸烟率, 但是巴林的吸烟率逐年呈上 升趋势。(中国健康教育研究所烟草控制与疾病预防研究室 潘学雷译) 